\title{
APPLICATION OF CONCEPTUAL RAINFALL-RUNOFF MODEL METQ FOR SIMULATION OF DAILY RUNOFF AND WATER LEVEL: THE CASE OF THE LAKE BURTNIEKS WATERSHED
}

\author{
Elga Apsite*, Ansis Ziverts, and Anda Bakute* \\ * University of Latvia, Faculty of Geography and Earth Sciences, Raina bulv. 19, Rīga LV-1586, LATVIA, \\ E-mail: elga.apsite@lu.Iv
}

Communicated by Oḷǵerts Nikodemus

\begin{abstract}
In this study a conceptual rainfall-runoff METQ model-the latest version METQ2007BDOPT — was applied to simulate the daily runoff and water level of the Lake Burtnieks watershed from 1990 to 1999. The model structure and parameters were basically the same as in the METQ98, with some additional improvements and semi-automatical calibration performance. Model calibration was done for four rivers and one lake gauging station. The results of calibration showed a good correlation between the measured and simulated daily discharges. The NashSutcliffe efficiency $\mathrm{R}^{2}$ varied from 0.90 to 0.58 and correlation coefficient $\mathrm{r}$ from 0.95 to 0.83 . The highest values of $R^{2}=0.90$ and $r=0.95$ were obtained for the River Salaca and the lowest $R^{2}=$ 0.53 and $\mathrm{r}=0.83$ for Lake Burtnieks. We observed some relationships between the model parameter values and physiographic characteristic of the sub-catchments.
\end{abstract}

Key words: conceptual rainfall-runoff model, optimisation of parameters, runoff routing, Lake Burtnieks.

\section{INTRODUCTION}

During the last centuries, many human management actions have been carried out in different watersheds all over the world. In fact, for the purposes of water resource assessment, design of engineered channels, flood forecasting, assessing impact of pollution sources on water quality, and many others, the availability of hydrological measurement data is limited in both temporal and spatial terms. One of the explanations for this is that not all parameters of hydrological processes and regimes can be measured. Therefore, in order to solve practical problems, extension of existing data is an important task in hydrology. One available method is the use of conceptual rainfall-runoff (also called precipitation-runoff or water balance) models which are widely used tools in hydrology (Seibert, 1999; Uhlenbrook et al., 1999; Beven, 2001; Zīverts and Apsīte, 2001). Contrary to more complex, physically-based, distributed models such as the SHE model (Abbott et al., 1986), the required input data are readily available for most applications. Furthermore, conceptual models are usually simple and relatively easy to use (Bergström, 1991; Bergström et al., 1996; Uhlenbrook et al., 1999; Merz and Blöschl, 2004). However, Bergström (1991) has pointed out that there should not be a conflict between the uses of physically based processoriented and the simpler conceptual based basin-oriented models because they are developed for different purposes and should be applied accordingly.
Since the 1960s, when computers started to become more widely available, conceptual storage models are still widely used today. One of the first and most successful of these models was the Stanford Watershed model developed by Norman Crawford and Ray Linsley (1966) at Stanford University. A number of conceptual rainfall-runoff models have been published in the hydrological literature. The most comprehensive overview for the period between 1958 and 1973 was given by Fleming (1975). The spatial scales of runoff process investigations vary from the plot scale dealing for example with the role of macropores up to a continental scale, when developing a water balance model to study the relationship between climate and water resources (Braun and Renner, 1992). A review of computer-based rainfall-runoff model examples, which are still in current use, may be found in the publication of Singh (1995). Examples of such models are the Sacramentio, HSPF and SSARR models from the USA, the HBV model from Sweden, the UBC model from Canada, the Tank model from Japan and the RORM model from Australia. However, the recently published monograph by Keith J. Beven (2001) is the first comprehensive introduction and survey of rainfallrunoff modelling since 1975, where the author has also shared the modeller's experience in the development and testing of many different hydrological models.

In Latvia, during the last twenty years, several versions of mathematical models of hydrological processes have been 
developed: METUL (Krams and Ziverts, 1993), METQ96 (Ziverts and Jauja 1996), METQ98 (Ziverts and Jauja, 1999), METQ2005 and METQ2006. In this paper the modelling results of the latest version METQ2007BDOPT are presented. The METQ is a conceptual rainfall-runoff model of catchment hydrology, originally developed using Latvian catchments. The model has been successfully applied to small and relatively large catchments, the Brook Vienziemite $\left(\mathrm{A}=5.92 \mathrm{~km}^{2}\right)$ and the River Daugava $(\mathrm{A}=81000$ $\mathrm{km}^{2}$ at the Plavinas HPP) respectively. Furthermore, the METQ model has been used for different hydrological tasks, i.e. to evaluate model performance before and after drainage construction and to estimate the eventual maximum flood (Ziverts and Jauja, 1999), to study eutrophication and hydrotehnical problems of lakes, including climate change effects (Ziverts and Apsìte, 2001; Bilaletdin et al., 2004; Ziverts and Apsite, 2005), to test model parameter sets for ungauged catchments from measurable variables and to simulate nutrients runoff in agricultural basins (Jansons et al., 2002; Apsite et al., 2005).

The aim of this study was to apply a conceptual rainfallrunoff METQ model, the latest version METQ2007BDOPT, to the Lake Burtnieks watershed for simulation of daily runoff and water level, and to find relationships between model parameter values and physiographic characteristic of the sub-catchment.

\section{MATERIALS AND METHODS}

The conceptual rainfall-runoff METQ model. The METQ model is a conceptual rainfall-runoff model of catchment hydrology which simulates daily discharge and evapotranspiration as input using the following variables: daily air temperature, precipitation and vapour pressure deficit observations. The model consists of different routines representing snow accumulation and ablation, water balance in root zone, water balance in groundwater and capillary water zone and runoff routing (Fig. 1). Runoff routing can be simulated by simple hydrological methods, such as modifications of the unit hydrograph approach. However, if there is a lake in the river basin, which considerably influences the hydrological regime of the river, hydraulic runoff routing is necessary. More detailed description of the model (METQ96 and METQ98) can be found in other sources (Ziverts un Jauja, 1996; Ziverts and Jauja, 1999). In general, the structure and simulation of hydrological processes of the METQ98 model are similar to the HBV (Bergström, 1976; 1992) model developed in Sweden. The main difference between the METQ98 and HBV models is that the degree-day ratio in METQ98 does not have a constant value, but rather a temporal difference, depending on the daily potential insolation of each particular day (Ziverts and Jauja, 1999).

The latest version of METQ2007BDOPT and its application. In this study, the mathematical model of the Lake Burtnieks watershed is based on the specific hydraulic routing model of the lake and the conceptual rainfall-runoff METQ model. Similarly to previous versions of the METQ

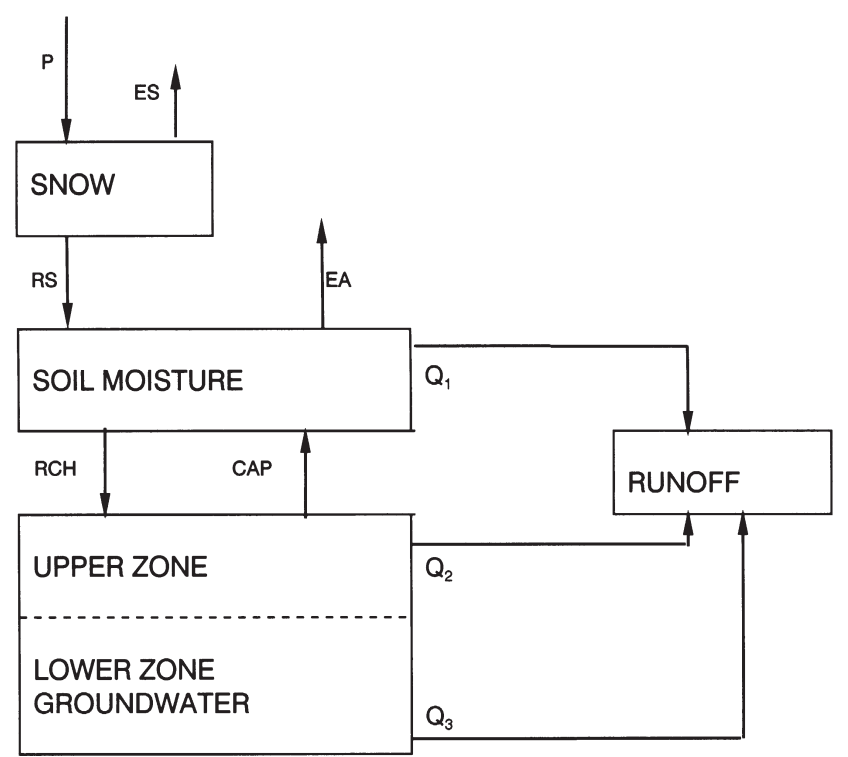

Fig. 1. General structure of the model for each hydrological response unit (Ziverts and Jauja, 1999). P, precipitation; ES, evaporation from snow; EA, evapotranspiration from root zone; $\mathrm{RS}$, rain and snowmelt water; $\mathrm{RCH}$, recharge to groundwater; CAP, capillary flow.

model, the latest version of the applied METQ2007BDOPT is used for the simulation of daily runoff and evapotranspiration for rivers with different catchment areas.

The model parameters are basically the same as for the METQ98 (Ziverts and Jauja, 1999). However, METQ2007BDOPT has one additional Beta parameter, providing twenty three parameters in total. Snow accumulation and melting is characterised by the following parameters: $\mathrm{T}_{1}$ - daily mean temperature ${ }^{\circ} \mathrm{C}$, at which snow accumulation starts; $T_{2}-$ daily mean temperature at which snow melting starts; CMELT - degree-day ratio and characterises intensity of snow melting; AMELT - conversion factor which increases the degree-day ratio based on the daily potential insolation of each particular day; KS - evaporation coefficient from snow; WHC and CFR characterise snow accumulation and melting processes. The water balance from root zone is characterised by: WMAX - threshold value of water storage in root zone (mm); KU and $\mathrm{KL}$ - coefficients characterising intensity of evaporation from root zone; RCHR (mm/d), RCHRZ (mm/d), RCHR2 (mm/d), RCHR2Z (mm/d) and ROBK - characterise the infiltration capacity of soil. The water balance of groundwater storage and runoff is characterised by the following parameters: ALFA - fillabale porosity of the aquifer; ZCAP - height of capillary rise (cm); DZ - depth of upper level drain from the surface $(\mathrm{cm}) ; \mathrm{A} 2$ and Beta characterise daily subsurface runoff $\mathrm{Q}_{2}$ of upper level „drain”; $\mathrm{PZ}$ characterises depth of the lower level "drain" (cm); A3 - daily runoff $\mathrm{Q}_{3}$ of the lower level "drain"; DPERC is intensity of deep percolation to the aquifers $(\mathrm{mm} / \mathrm{d})$. Most of the parameters in the model are physically based and the rest of parameters usually can be estimated by the calibration. The METQ2007BDOPT has semi-automatic calibration performance for the follow- 
OPTIMAL PARAMETER VALUES OF THE METQ2007BDOPT MODEL FOR THE RIVER SUB-BASINS WITH GAUGING STATIONS OF LAKE BURTNIEKS WATERSHED

\begin{tabular}{|c|c|c|c|}
\hline \multirow[t]{2}{*}{ Parameter* } & \multicolumn{3}{|c|}{ River basin and hydrological gauging station } \\
\hline & $\begin{array}{c}\text { Briede - } \\
\text { Dravnieki }\end{array}$ & Seda - Oleri & Rūja - Vilnīši \\
\hline WMAX, mm & 62 & 64 & 60 \\
\hline ALFA & 0.163 & 0.170 & 0.150 \\
\hline $\mathrm{ZCAP}, \mathrm{cm}$ & 143 & 140 & 140 \\
\hline $\mathrm{A} 2$ & 0.00063 & 0.00058 & 0.00060 \\
\hline $\mathrm{DZ}, \mathrm{cm}$ & 84 & 81 & 72 \\
\hline A3 & 0.00075 & 0.00074 & 0.00072 \\
\hline $\mathrm{PZ}, \mathrm{cm}$ & 260 & 240 & 260 \\
\hline BETA & 2.1 & 2.1 & 2.1 \\
\hline KU & 0.62 & 0.63 & 0.63 \\
\hline KL & 0.24 & 0.28 & 0.28 \\
\hline KS & 0.05 & 0.05 & 0.05 \\
\hline CMELT & 2.5 & 2.5 & 2.5 \\
\hline AMELTK & 0.05 & 0.08 & 0.08 \\
\hline $\mathrm{T} 1,{ }^{0} \mathrm{C}$ & 0.5 & 0.5 & 0.5 \\
\hline $\mathrm{T} 2,{ }^{0} \mathrm{C}$ & -0.1 & -0.1 & -0.1 \\
\hline $\mathrm{RCHR}, \mathrm{mm} / \mathrm{d}$ & 18 & 16 & 16 \\
\hline $\mathrm{RCHRZ,} \mathrm{mm/d}$ & 25 & 25 & 25 \\
\hline $\mathrm{RCHR} 2, \mathrm{~mm} / \mathrm{d}$ & 26 & 25 & 25 \\
\hline RCHR2Z, mm/d & 20 & 20 & 20 \\
\hline ROBK & 1.5 & 1.5 & 1.5 \\
\hline WHC & 0.1 & 0.1 & 0.1 \\
\hline CFR & 1.2 & 1.2 & 1.2 \\
\hline DPERC, $\mathrm{mm} / \mathrm{d}$ & 0.0 & 0.0 & 0.0 \\
\hline
\end{tabular}

* See parameter abbreviations in Materials and Methods.

ing parameters-A2, DZ, A3, PZ, CMELT, AMELT, DPERC, Beta, RCHR, RCHR2, RCHRZ, and RCHRZ2. A number of parameter sets are sampled using the MonteCarlo technique from the prior parameter distributions. The model is run using these parameter sets and the model outcome of each run is compared to the observed values using the selected objective function: Nash-Sutcliffe efficiency $R^{2}$ (Nash and Sutcliffe, 1970). Finally, those parameter sets giving the highest values of $R^{2}$ and realistic likelihood were tested. In this study the used optimal parameter values for the conceptual rainfall-runoff METQ2007BDOPT model are shown in Table 1 and Table 2.

Daily meteorological data were used as input data for the METQ2007BDOPT model. Measurements of air temperature, precipitation and vapour pressure deficit at five meteorological stations were used for preparing the climatic data series. For the model calibration time, series of at least five year period of daily river discharge and water level of the lake (in this study, Lake Burtnieks) of five hydrological gauging stations were applied. The locations of meteorological and gauging stations are showed in Figure 2. Calibration of the model was made for different periods of available hydrological observation records from 1990 to 1999. A statistical criterion $R^{2}$ (Nash and Sutcliffe, 1970), a correlation coefficient $r$, mean values and graphical repre-
OPTIMAL PARAMETER VALUES OF THE METQ2007BDOPT MODEL FOR THE RIVER SUB-BASINS OF LAKE BURTNIEKS WATERSHED

\begin{tabular}{|c|c|c|c|c|c|}
\hline \multirow[t]{2}{*}{ Parameter* } & \multicolumn{5}{|c|}{ Sub-basin } \\
\hline & Briede & Seda & Rūja & Burtnieks & Mazsalaca \\
\hline WMAX, mm & 62 & 64 & 63 & 62 & 62 \\
\hline ALFA & 0.163 & 0.170 & 0.150 & 0.163 & 0.163 \\
\hline $\mathrm{ZCAP}, \mathrm{cm}$ & 143 & 140 & 140 & 143 & 143 \\
\hline $\mathrm{A} 2$ & 0.00063 & 0.00058 & 0.00060 & 0.00063 & 0.00063 \\
\hline $\mathrm{DZ}, \mathrm{cm}$ & 84 & 81 & 72 & 84 & 84 \\
\hline A3 & 0.00075 & 0.00074 & 0.00075 & 0.00075 & 0.00075 \\
\hline $\mathrm{PZ}, \mathrm{cm}$ & 260 & 240 & 260 & 260 & 260 \\
\hline BETA & 2.1 & 2.1 & 2.1 & 2.1 & 2.1 \\
\hline $\mathrm{KU}$ & 0.58 & 0.59 & 0.63 & 0.58 & 0.58 \\
\hline KL & 0.20 & 0.20 & 0.23 & 0.20 & 0.20 \\
\hline $\mathrm{KS}$ & 0.05 & 0.05 & 0.05 & 0.05 & 0.05 \\
\hline CMELT & 2.5 & 2.5 & 2.5 & 2.5 & 2.5 \\
\hline AMELTK & 0.05 & 0.08 & 0.08 & 0.05 & 0.05 \\
\hline $\mathrm{T} 1,{ }^{0} \mathrm{C}$ & 0.5 & 0.5 & 0.5 & 0.5 & 0.5 \\
\hline $\mathrm{T} 2,{ }^{0} \mathrm{C}$ & -0.1 & -0.1 & -0.1 & -0.1 & -0.1 \\
\hline $\mathrm{RCHR}, \mathrm{mm} / \mathrm{d}$ & 18 & 16 & 16 & 18 & 18 \\
\hline $\mathrm{RCHRZ,} \mathrm{mm/d}$ & 25 & 25 & 25 & 25 & 15 \\
\hline $\mathrm{RCHR} 2, \mathrm{~mm} / \mathrm{d}$ & 26 & 25 & 25 & 26 & 16 \\
\hline $\mathrm{RCHR} 2 \mathrm{Z}, \mathrm{mm} / \mathrm{d}$ & 20 & 20 & 20 & 20 & 20 \\
\hline ROBK & 1.5 & 1.5 & 1.5 & 1.5 & 1.5 \\
\hline WHC & 0.1 & 0.1 & 0.1 & 0.1 & 0.1 \\
\hline CFR & 1.2 & 1.2 & 1.2 & 1.2 & 1.2 \\
\hline DPERC, $\mathrm{mm} / \mathrm{d}$ & 0.0 & 0.0 & 0.0 & 0.0 & 0.0 \\
\hline
\end{tabular}

* See parameter abbreviations in Materials and Methods

sentation were used in the analyses of model calibration results.

The lake watershed was divided into four sub-basins (the Rūja, the Seda, the Briede and Lake Burtnieks (small rivers entering the lake) and one additional sub-basin between the outlet of the lake and the runoff gauging station Mazsalaca at the River Salaca (Fig. 2). The modelling of Lake Burtnieks watershed sub-basins was done using the METQ2007BDOPT version, by testing the following updates: (1) calculation of daily average discharge and water level in Lake Burtnieks based on daily average temperature and precipitation data from the nearest meteorological stations; calculation of evapotranspiration from the drainage basin by using climatic parameters of the corresponding calendar days; (2) optimisation of parameters (fitting to larger sub-basin) was performed using the observed data from three river runoff gauges: Rūja - Vilnīši A $=729 \mathrm{~km}^{2}$, Seda - Oleri A $=431 \mathrm{~km}^{2}$, Briede - Dravnieki A $=369$ $\mathrm{km}^{2}$; (3) runoff routing of the Lake Burtnieks simulated on the basis of common hydraulic methods of reservoirs and open channels: the relation between water level and volume was estimated from geometrical dimensions of the lake, and discharge rating curve $\mathrm{Q}=\mathrm{f}(\mathrm{H})$ at the outlet of the Lake Burtnieks for the River Salaca was calculated as for a parabolic river bed with a parabolic parameter, defined by the simulated average daily discharge and the given water sur- 


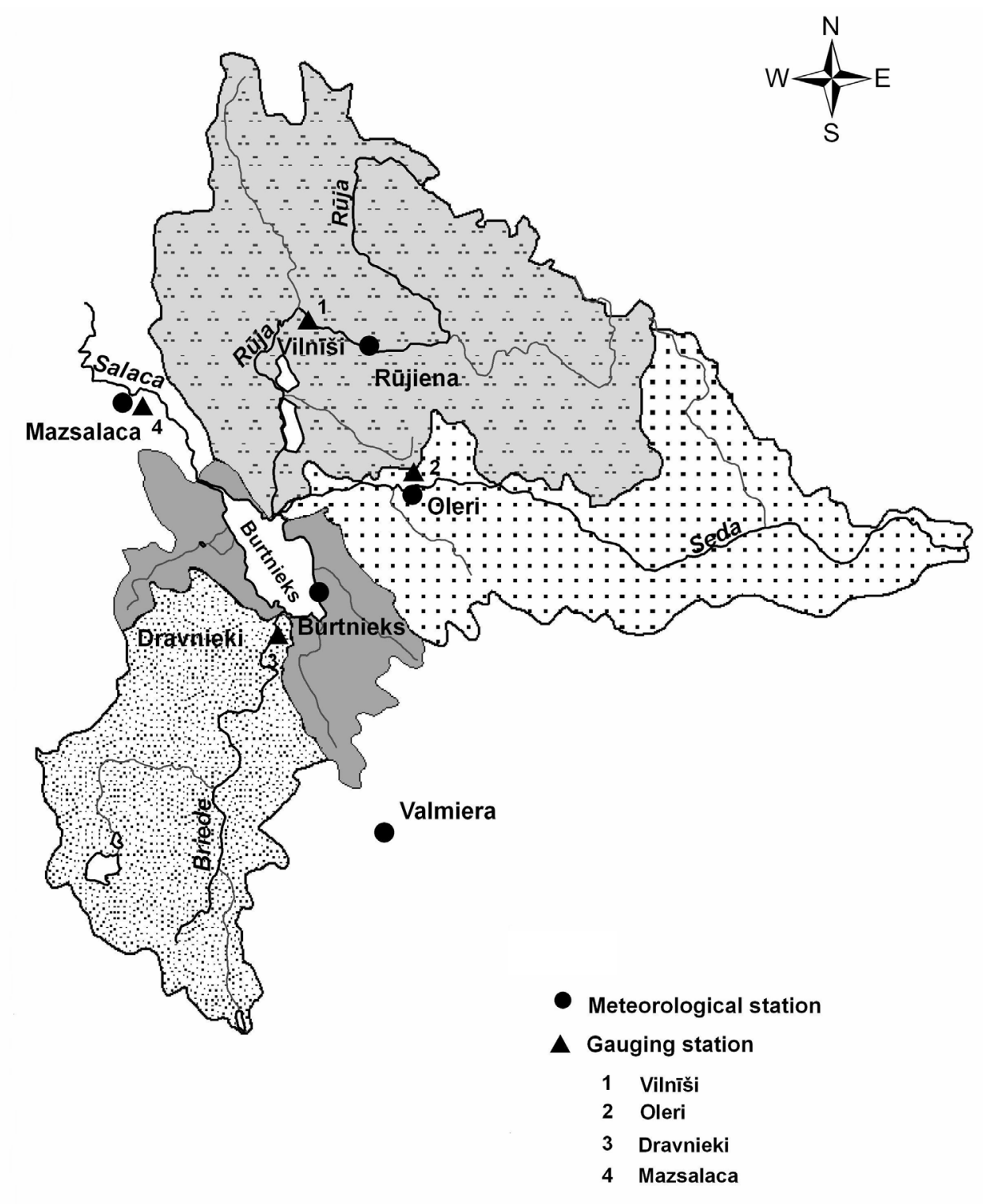

Fig. 2. Sub-basins, gauging and meteorological stations in Lake Burtnieks Watershed.

face slope. There was a lack of channel measurements at the outlet of the lake and $\mathrm{Q}=\mathrm{f}(\mathrm{H})$ was obtained on the basis of typical parameters for river channels in Latvia (Golubovskis, 1993).

To consider the runoff heterogeneity in the runoff processes, the studied catchment was divided into hydrological response units (HRU) characterised by a relative homogeneity with respect to the most important parameters, which include slope, vegetation and soil characteristics. The catchment area was divided into six HRUs: agricultural lowlands, hilly agricultural lands, forests, swamps, lakes, and sandy lowlands. The last one was introduced into the METQ2005, the METQ2006 and METQ2007BDOPT versions as an additional geomorphologically important HRU (sandy lowlands) and it has improved the modelling results of runoff in likely sandy catchments.
The water balance and runoff of each HRU has been simulated in three storages: snow (water content in snow cover), soil moisture (water in the root zone) and groundwater (Fig. 1). The total runoff from each of HRU consists of three runoff components: $\mathrm{Q}_{1}$ - surface runoff, $\mathrm{Q}_{2}-$ subsurface runoff (runoff from the groundwater upper zone) and $\mathrm{Q}_{3}-$ base flow (runoff from the groundwater lower zone).

Study site. Lake Burtnieks (before 1366 called Lake Astjervs), the fourth largest lake in Latvia, is located in the north-east of Latvia, $39.5 \mathrm{~m}$ above the sea level. The lake is the source of the River Salaca and The North Vidzeme Biosphere Reserve-one of the largest nature reserves in Latvia is located in its valley.

The surface area of the lake is $40.06 \mathrm{~km}^{2}$. Lake Burtnieks is shallow, with average depth $2.2 \mathrm{~m}$ and maximum depth 3.3 
$\mathrm{m}$; the length from SE to NW $13.3 \mathrm{~km}$ and coast line $33 \mathrm{~km}$. Water renewal occurs 6-7 times per year. Short retention times were observed in spring (water renewal once in 2-3 weeks) while in summer water renewal occurs in three months (Rodinovs un Kḷaviņš, 1993).

The inflowing rivers of Lake Burtnieks are River Rūja (992 $\mathrm{km}^{2}$ ), River Seda $\left(543 \mathrm{~km}^{2}\right)$, the River Briede $\left(444 \mathrm{~km}^{2}\right)$ and 27 smaller rivers. The three largest rivers contribute $73-75 \%$ of the total discharge into the lake. The only outflow is the River Salaca which runs into the Baltic Sea. The total drainage area of the lake is $2215 \mathrm{~km}^{2}$ which occupies $62 \%$ of the River Salaca catchment.

The climate is temperate, cool and humid. The average temperature of year ranges from +5.0 to $+5.5{ }^{\circ} \mathrm{C}$. The mean temperature is $-6.5{ }^{\circ} \mathrm{C}$ in January and $+17{ }^{\circ} \mathrm{C}$ in July. The average amount of precipitation ranges from 650 to $760 \mathrm{~mm}$ per year.

The study area is located in the Burtnieks Plain which can be considered as a constituent part of the North Vidzeme Lowland. Lake Burtnieks is situated in the lowest central part of the bedrock macrodepression. The bedrock (subquaternary) surface mainly consists of weakly cemented Middle Devonian sandstone of the Burtnieks Formation, in some places inter-bedded with thin siltstone and shale. The bedrock macrodepression widens in the direction of regional glacier movement. This caused a divergent flow in the North-Vidzeme glacier tongue (Zelčs and Dreimanis, 1997). The bedrock is covered by Quaternary deposits. The thickness of the Quaternary cover varies from 10 to 20 metres and reaches up to 40 metres in the highest parts of the topography. The deposits are mainly glacial sediments such as sand, gravel and pebble mixture, clayey sandy till and sandy clayey till as well as glaciotectonically deformed and non-deformed sand, silt and clay. The eolian sediments are located in the lower reaches of the watersheds of the rivers Rūja and Seda. In the depressions between the drumlins, glacial sediments are covered by peat, but in river valleys by alluvial sediments (Zelčs, 1995). The surface of the Burtnieks Plain is sligtly undulating with a typical drumlin landscape.

Lake Burtnieks is located in the deepest part of the shallow depression shaped by glacial erosion in the central part of the Burtnieks drumlin field (Zelčs, 1995). The bottom of the lake slopes towards the ice movement as well as to the crests of the drumlins. In former times the water body of Lake Burtnieks originating from melting ice was 4-5 times larger than now and covered mainly the lower reaches of the rivers Rūja and Seda. Ever since that time the area has become swampy and covered with forest (Tidrikis, 1995). The main types of the soil are sod-podzolic, sod-pseudogley and typical podzols in the highest parts of the landscape. There is sod-gleysolic, podzolic-gley, humus-podzolic gley and bog humus soil in depressions and alluvial soils in the river valleys and around lakes (Bilaletdin et al., 2004). Agricultural land covers $30-40 \%$ of the Lake Burtnieks watershed and the largest areas are located in the vicinity of populated areas Rūjiena and Burtnieki. Wetlands cover about $10 \%$, forests (mostly mixed and coniferous) about $40-50 \%$ and waters less than $3 \%$ of the lake drainage basin. The largest bog areas are located in the drainage basins of the rivers Rūja and Seda.

During the last centuries, different management actions have been carried out in the Lake Burtnieks watershed. The water level of the lake dropped by $1 \mathrm{~m}$ after the regulation measures of the River Salaca carried out in 1929. The surface area of the lake was changed from $35.49 \mathrm{~km}^{2}$ in 1932 to $40.06 \mathrm{~km}^{2}$ in 1992 . In the $1980 \mathrm{~s}$, the lake was highly eutrophic. The overgrown surface area of the lake changed from $5 \%$ in 1952 to $20-25 \%$ in 1992 (Bilaletdin et al., 2004).

\section{RESULTS}

In the present study the mathematical model of Lake Burtnieks watershed was calibrated in two ways: (1) three river sub-basins of the Lake Burtnieks watershed were calibrated using river gauging stations (Briede-Dravnieki, Rūja-Vilnı̄ši and Seda-Oleri) and (2) the whole watershed of the Lake Burtnieks was calibrated for the SalacaMazsalaca river gauging station and the BurtnieksBurtnieki lake gauging station.

In the first case, the results of model calibration showed sufficient or even good correlation between the observed and simulated daily discharges (Fig. 3: A, B, C). Correlation coefficient $r$ was 0.92 and efficiency criterion $R^{2}=0.83$ for the River Briede at Dravnieki (calibration period 19901997), $r=0.87$ and $R^{2}=0.68$ for the River Seda at Oleri (calibration period 1994-1999). A slightly weaker correlation between observed and simulated hydrographs was found for the River Rūja at Vilnīši $\left(r=0.82\right.$ and $R^{2}=0.66$, calibration period 1994-1999). Optimised parameters of the METQ2007BDOPT model for the river sub-basins with runoff gauging stations of the Lake Burtnieks watershed are presented in the Table 1. The numerical values of the model parameters for each sub-basin reflect some geomorphologic conditions of the studied drainage area.

In the second case, the model calibration shows sufficient fluctuations between simulated and observed water levels of Lake Burtnieks for a seven-year period from 1993 to 1999: the Nash-Sutcliffe efficiency $R^{2}$ was 0.58 and the correlation coefficient $r=0.83$ (Fig. 4). However, a very good coincidence between the observed and simulated daily discharges was obtained for the River Salaca basin at Mazsalaca (Fig. 5): the efficiency criterion $R^{2}$ was 0.90 and correlation coefficient $r=0.95$ (calibration period 1994-1998). Table 2 shows the used values of model parameters for the river sub-basins of the whole Lake Burtnieks watershed (the METQ2007BDOPT model was calibrated at the Salaca-Mazsalaca and Burtnieks-Burtnieki gauging stations). 

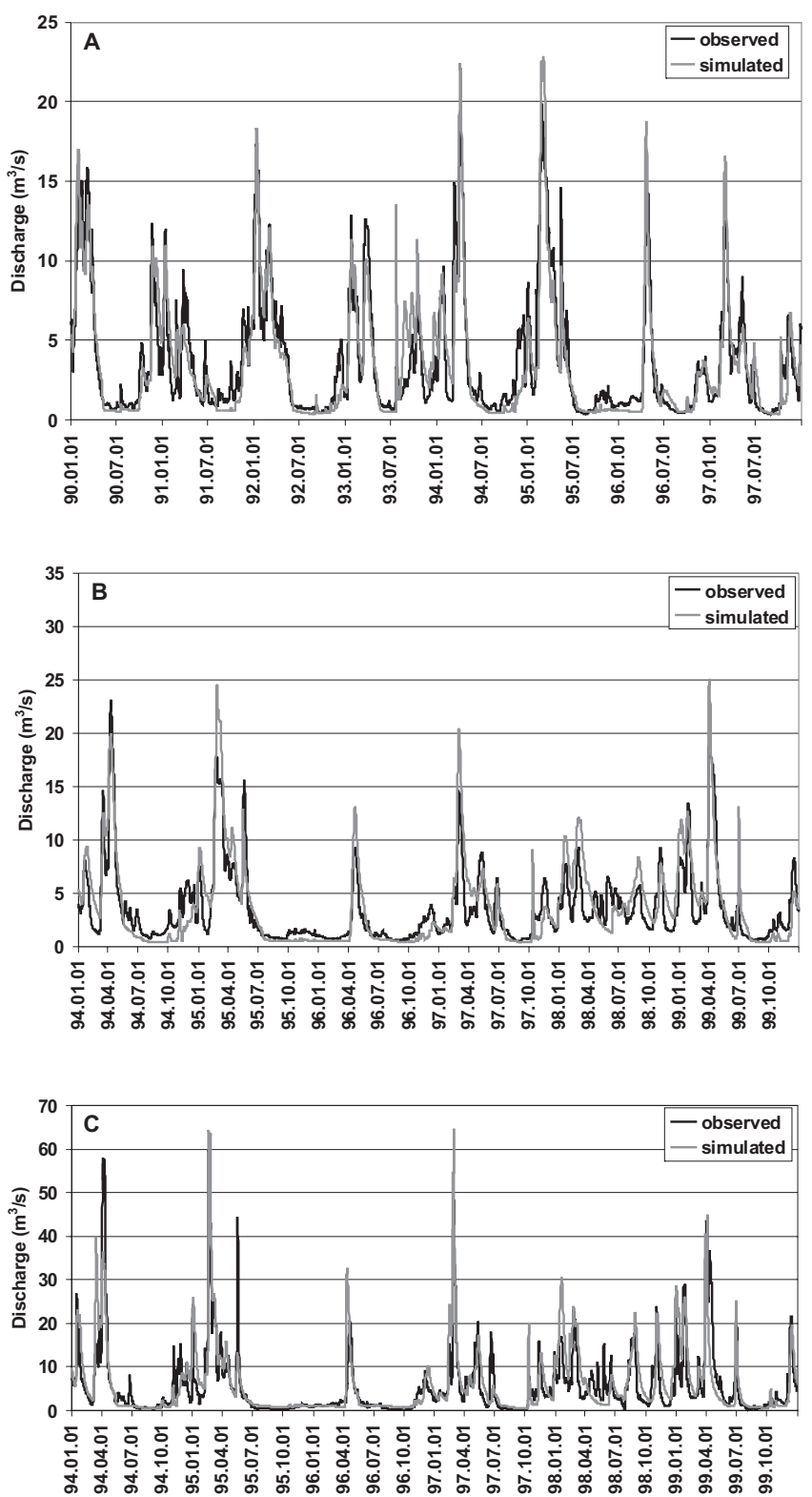

Fig. 3. Observed and simulated daily discharge at the river gauging stations: A, Briede-Dravnieki, B, Seda-Oleri, and C, Rūja-Vilnǐši.

\section{DISCUSSION}

Hydrology conceptual rainfall-runoff models are widely used tools today. One of the advantages is that models are usually simple and relatively easy to use. The required input data are readily available for most applications (Uhlenbrook et al., 1999). In this investigation, the data series of at least a five-year period of four river (the River Briede - Dravnieki, the River Rūja - Vilnīši, the River Seda - Oleri and the River Salaca - Mazsalaca) and one lake (Burtnieki) gauging stations were used for the calibration of the conceptual rainfall-runoff METQ2007BDOPT model for the Lake Burtnieks watershed. For such a drainage area, the number of observation points and the calibration periods is sufficient.

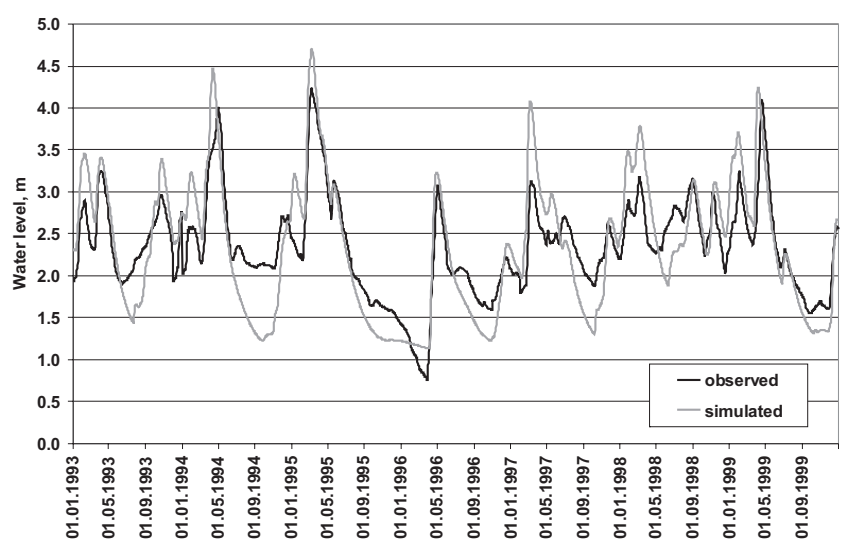

Fig. 4. Observed and simulated daily water level at the lake gauging station Burtnieks-Burtnieki.

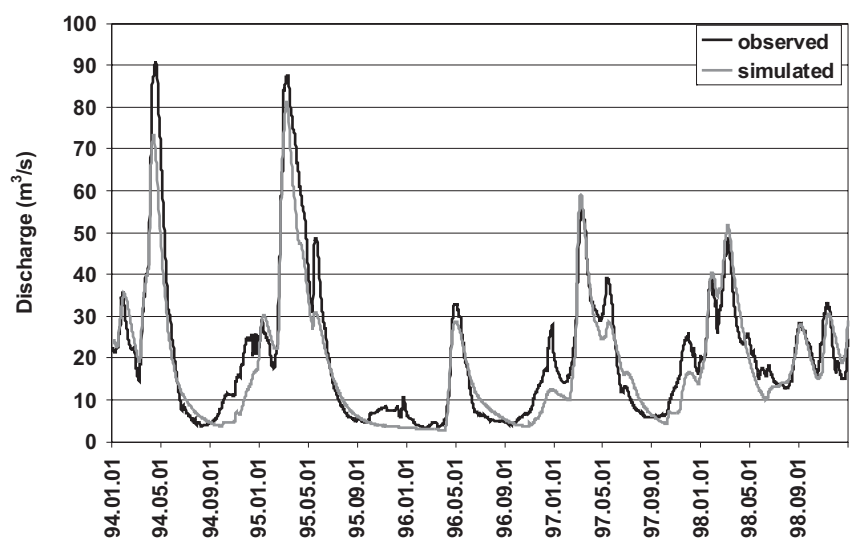

Fig. 5. Observed and simulated daily discharge at the river gauging station Salaca-Mazsalaca.

The results of calibration showed good coincidence between the measured and simulated daily discharges (Fig. 3: A, B, C, Fig. 4 and Fig. 5). The Nash-Sutcliffe efficiency $R^{2}$ varied from 0.90 to 0.58 and correlation coefficient $r$ from 0.95 to 0.83 . The highest $R^{2}$ and $r$ was acquired for the River Salaca. The lowest statistical criterions were found for the River Rūja and Lake Burtnieks. One of the main sources of difference between the simulated and observed runoff values is the quality of precipitation input data and location of the available meteorological stations to characterise the spatial and temporal distribution of precipitation in the studied drainage area. For example, the meteorological station Rūjiena is located in the middle part of the River Rūja basin. We suppose that the model METQ2007BDOPT calibration results could be improved by better quality of precipitation data.

Another explanation of the above mentioned calibration differences could be a broad palufied flood plain and a high percentage of wetlands in the rivers Seda and Rūja drainage basins. Thus, there may be a specific hydrological regime which differs from the other studied rivers (e.g., the River 
Briede) and it is difficult to simulate the rainfall-runoff processes without additional riverbed measurements. As mentioned before, runoff routing of Lake Burtnieks was simulated on the basis of common hydraulic methods of reservoirs and open channels. If channel measurements were available at the outlet of the lake we could obtain better correlation between simulated and observed water level (Fig. 4). Singh (1995) found that all rainfall-runoff models can only be approximate descriptions of rainfall-runoff processes and, as such, must be considered to be uncertain in their predictions. However, for many practical purposes, we do not need to include all details in developing a predictive model. Indeed, many successful rainfall-runoff models are essentially very simple. In such models most parameters are not measurable but have to be estimated by calibration using at least some observed runoff data (Seibert, 1999).

The extension of runoff series in time by the use of models is rather straightforward. On the other hand, extension in space, e.g., regionalisation of conceptual rainfall-runoff models, is more difficult. The typical approach is to look for relationships between optimised parameter values and catchment characteristics. Then parameter sets can be compiled for ungauged catchments from measurable variables. During the past decades this approach has been tested by several scientists with varying success (Hughes, 1989; Servat and Dezetter, 1993; Braun and Renner, 1992; Ibrahim and Cordery, 1995, Seibert, 1999; Merz and Blöschl, 2004; Parajka et al., 2005; Götzinger and Bịrdossy, 2007). Seibert (1999) concluded that the general problem in the regionalisation of model parameters is the limited number of catchments usually available and that model parameters often are badly defined. Also there is a risk for bias in the model calibration. This risk is obvious for manual calibration, because the modeller may search the optimal parameters influenced by what he/she expects. Using automatic calibration procedures different parameter sets may be found depending on, e.g., start values of the parameter search (Kite and Kouwen, 1992).

The regionalisation of the METQ2007BDOPT model parameters for river basins in Latvia could be another interesting issue for further research. In this study we tried to find the relationships between the model parameter values with semi-automatic calibration performance and physiographic sub-catchment characteristics. The analysis of METQ2007BDOPT optimised parameters in Table 1 and 2 shows that the numerical values of the model parameters obtained for each sub-basin reflected some physiographic conditions. The studied river sub-basins could be divided into two groups: (1) Rūja and Seda, and (2) Briede, Burtnieks and Mazsalaca. The river basins of Rūja and Seda are located in the Burtnieks Plain and are characterised by a lower hypsometry, sandy and moraine areas, a high coverage of bogs and flood plain in lower reaches. The River Briede basin is characterised by the moraine hilly topography and bog areas. The geomorphologic conditions of the sub-basins Burtnieks and Mazsalaca are more similar to the River Briede basin. Some of the optimised model parame- ters were estimated from previous experience, e.g., water storage in root zone (WMAX) based on the previous studies of irrigation regime in Latvia (Sauka, 1970). Determination of fillabale porosity (ALFA) and height of capillary rise (ZCAP) depend on the hydrophysical characteristics of most common types of soils. Both parameters depend on soil texture. In this case, the sub-basins Rūja and Seda are characterised by the sandy areas and the value of parameters ALFA and ZCAP is lower (Table 1 and 2). The second group of sub-basins has higher average values of parameters which are semi-automatically calibrated and describe the subsurface drainage (A2, DZ) and the drainage capacity of deeper layers (A3, PZ). These drainage areas are characterised by hilly agricultural lands with deeper infiltration efficiency. Also, the similarity of physiographic conditions (climate, topography, soil, land-use, and geomorphology) of the studied sub-basins was found for the group of parameters describing the process of surface runoff generation.

The obtained results of model calibration show that the model METQ2007BDOPT for the Lake Burtnieks is widely applicable, including simulation of different hydrological processes in the watershed-daily runoff of rivers and water level fluctuations of the lake.

\section{ACKNOWLEDGEMENTS}

This study was supported by the National Research Programme Climate Change Impact on Water Environment in Latvia and by the European Social Fund (ESF), for financial support in Doctoral studies of Anda Bakute. Data was provided by the Latvian Environment, Geology and Meteorology Agency and SIA Melioprojekts. The authors would like to thank also Professor Ansis Zivverts for generously provided consultations and knowledge about modelling basics.

\section{REFERENCES}

Abbott, M.B., Barthurst J.C., Cunge J.A., O'Connell P.E., Rasmussen J. (1986). An introduction to the European Hydrologic System-Système Hydrologique Européen "SHE”. Pt. 2: Structure of physically based, distributed modelling system. J. Hydrol., 87, 61-77.

Apsīte, E., Kokorīte, I., Zīverts, A., Kḷaviṇš, M. (2005). Pierīgas mazo upju raksturojums. LU 63. Zinātniskā conference, 2005. gada 4. februārī. Geogrāfijas sekcijas tēzes. Rīga, 11. 1pp.

Bergström, S. (1976). Development and application of a conceptual runoff model for Scandinavian catchments. SMHI (Swedish Meteorologicaland Hydrological Institute) Report, No. RHO7.

Bergström, S. (1991). Principles and confidence in hydrological modelling. Nordic Hydrology, 22, 123-136.

Bergström, S. (1992). The HBV model-Its structure and applications. SMHI Reports Hydrology, No. 4, 33.

Bergström, S., Carlsson, B., Graham, L.P. (1996). Modelling the water balance of the Baltic Basin-preliminary results. In Proceedings of XIX Nordic Hydrology Conference, 13-15 August 2006, Akureyri, Iceland, August (pp. 446-455).

Beven, K.J. (2001). Rainfall-Runoff Modelling. The Primer. New York: John Wiley\&Sons Ltd. 360 pp. 
Bilaletdin, Ä., Frisk, T., Kaipainen, H., Paananen, A., Perttula, H., Klavins, M., Apsite, E., Ziverts A. (2004). Water protection project of Lake Burtnieks. The Finnish Environment, Tampere, No. 670, 92.

Braun, L.N., Renner, C.B. (1992). Application of conceptual runoff model in different physiographic regions of Switzerland. Hydrol. Sci. J., 37(3), 217-231

Crawford, N.H., Linsley R.K. (1966) Digital simulation in hydrology: Stanford Watershed Model IV. Technical Report No. 39, Department of Civil Engineering, Stanford University, CA.

Fleming, G. (1975). Computer Simulation Techniques in Hydrology. New York: Elsevier. 333 pp.

Golubovskis, Ē. (1993). Noteku un upju regulēto gultnu hidraulikas un noturības problēmas [Problems of Hydraulics and Stability on Small Regulated Riverbeds]. Jelgava: LLU. 30 lpp.

Götzinger, J., Bárdossy, A. (2007). Comparison of four regionalisation methods for a distributed hydrological model. J. Hydrol., 333, 374-384.

Hughes, D.A. (1989) Estimation of the parameters of an isolated event conceptual model from physical catchment characteristics. Hydrol. Sci. J., 34(5), 539-557.

Ibrahim, A.B., Cordery, I. (1995). Estimation of recharge and runoff volumes from ungauged catchments in eastern Australia. Hydrol. Sci. J., 40(4), 499-515.

Jansons, V., Vagstad, N., Sudars, R., Deelstra, J., Dzalbe, I., Kirsteina D. (2002). Nutrient losses from point and diffuse agricultural sources in Latvia. Landbauforschung Völkenrode, 1(52), 9-17.

Kite, G.W., Kouwen, N. (1992). Watershed modelling using land classifications. Water Resources Res., 28(12), 3193-3200.

Krams, M., Ziverts, A. (1993). Experiments of conceptual mathematical groundwater dynamics and runoff modelling in Latvia. Nordic Hydrol., 24, 243-262.

Nash, J.E., Sutcliffe, J.V. (1970). River flow forecasting through conceptual models. Pt. IA discussion of principles. J. Hydrol., 10, 282-290.

Merz, R., Blöschl, G. (2004). Regionalisation of catchment model parameters. J. Hydrol., 287, 95-123.

Parajka, J., Merz, R., Blöschl, G. (2005). A comparison of regionalisation methods for catchment model parameters. Hydrol. Earth Sci., 9, 157-171.

Rodinovs, V., Kḷaviņš, M. (1993). Salacas upes hidroḳīmiskais raksturojums [Hydrochemical characteristics of the River Salaca]. Vides aizsardziba Latvijā, Rīga, 51.-56. lpp. (in Latvian).
Seibert, J. (1999). Regionalization of parameters for a conceptual rainfall-runoff model. Agricultural Forest Meteorol., No. 98/99, 279-293.

Servat, E., Dezetter, A. (1993). Rainfall-runoff modelling and water resources assessment in northwestern Ivory Coast. Tentative extension to ungauged catchments. J. Hydrol., 148, 231-248.

Singh, V.P. (1995). Computer models of watershed hydrology. Highlands Ranch, CO: Water Resource Publications. 1130 pp.

Tidrikis, A. (1995). Burtnieks [Lake Burtnieks]. Grām.: Latvija un Latvieši (enciklopēdija). 5. sēj. Latvijas Daba. Rīga: Preses nams, 174.-175 lpp. (in Latvian).

Uhlenbrook, S., Seibert, J., Leibundgut, C., Rodhe, A. (1999). Prediction uncertainty of conceptual rainfall-runoff models caused by problems in identifying model parameters and structure. Hydrol. Sci. J., 44(5), 779-797.

Zelčs, V. (1995) Burtnieka līdzenums [Lake Burtnieks Plain]. Grām.: Latvija un Latvieši (enciklopēdija). 5. sēj. Latvijas Daba. Rīga: Preses nams, 174.-175 lpp. (in Latvian).

Zelčs, V., Dreimanis, A. (1997) Morphology, Internal Structure and Genesis of the Burtnieks Drumlin Field, Northern Vidzeme, Latvia. J. Sedimentary Geol., 111(1-4), pp. 73-90.

Zīverts, A., Jauja, I. (1996) Konceptuālais matemātiskais modelis METQ96 ikdienas caurplūdumu aprēḳināšanai, izmantojot meteoroloğiskos novērojumus [Conceptual mathematical model METQ96 for the calculation of daily discharge using meteorological observations]. LLU Raksti, 6, 126-133 (in Latvian).

Ziverts, A., Jauja, I. (1999) Mathematical model of hydrological processes METQ98 and its applications. Nordic Hydrology, 30(2), 109-128.

Ziverts, A., Apsite, E. (2001) Watershed modelling of the Lake Burtnieks in the present conditions and considering the effect of climate change. In Proceedings of the 9th International Conference on the Conservation and Management of Lakes, 12-16 November 2001 (pp. 292-295). Biwako, Japan.

Zīverts, A., Apsīte, E. (2001). Noteces matemātiskā modelēšana Burtnieka un Lubāna ezera sateces baseiniem [Mathematical modelling of the runoff for the Lake Burtnieks and Lake Lubāns watersheds]. Geogrāfiski raksti (Follia Geographica), Rīga, 9, 11-19 (in Latvian).

Ziverts, A., Apsite, E. (2005). Simulation of daily runoff and water level for the Lake Burtnieks. In Proceedings of the 19th European Conference on Modelling and Simulation ECMS 2005, Simulation in Wider Europe, 1-4 June (pp. 633-637). Merkuryev, Y., Zobel, R., Kerckhoffs, E. (eds.). Riga.

Received 7 May 2008

\section{KONCEPTUĀLĀ NOKRIŠN̦U-NOTECES METQ LIETOŠANA IKDIENAS NOTECES UN ŪDENS LİMEN̦A SIMULĒŠANĀ: BURTNIEKU EZERA BASEINA PIEMĒRS}

Pētījuma mērkis bija izmantot konceptuālo nokrišṇu-noteces METQ modeḷa pēdējo versiju METQ2007BDOPT Burtnieku ezera baseina ikdienas noteces un ūdens līmeņa simulēšanā un atrast likumsakarības starp modeḷa parametriem un kalibrējamo apakšbaseinu fizioǵeogrāfiskajiem apstākḷiem. METQ modelis un vairākas tā versijas (METQ96, METQ98, METQ2005 un METQ2006) izstrādātas Latvijas Lauksaimniecības universitātes profesora A. Zīverta (1935-2007) vadībā 20. gadsimta deviṇdesmitajos gados un lietotas dažāda lieluma Latvijas upju un ezeru baseinu modelēšanā. Pēdējā versijā METQ2007BDOPT papildināta ar vienu kalibrējamo parametru beta un modeḷa parametru pusautomātiskās kalibrācijas iespēju. Burtnieku ezera baseins bija sadalīts četros upju apakšbaseinos un kalibrēts uz hidroloǵisko novērošanas staciju Salaca-Mazsalaca. Modeḷa kalibrācijas rezultāti parādīja labu sakritību starp novērotajiem un modelētajiem upju ikdienas caurplūdumiem un ezera ūdens līmeņiem: statistiskais kritērijs $R^{2}$ bija no 0.90 līdz 0.58 un korelācijas koeficients $r$ - no 0.95 lìdz 0.83 . 